\title{
DE
}

OPEN

\section{Instructional DVD video lesson with code switching: its effect on the performance level in dancing social dance among grade 10 special program in the art students of the Philippines}

\author{
Fernando T. Capilitan, Jr. \\ University of Science and Technology of Southern Philippines \\ fercaps@gmail.com
}

\begin{abstract}
This paper shows that the experimental group who are exposed to DVD Video Lesson that uses code switching language has an average mean score in the pretest of 1.56 , and this increased to an average mean of 3.50 in the posttest. The control group that uses DVD Video Lesson that uses purely English language got an average mean of 1.06 in the pretest and increased to 1.53 in the posttest. Based on the results of the performance posttest taken by the two groups, the experimental group has a dramatic increase in scores from the pretest to posttest. Although both groups had increased in their performance scores from pretest to posttest, the experimental group (code switching language) performs well in the posttest than the control group. As revealed in this findings, there is a significant difference in the posttest scores between the experimental group who are exposed to DVD lesson that uses code switching as a medium of instruction and the control group who are exposed to DVD lesson that uses English. The students who are exposed to the Video Lesson that uses code switching perform well than those students who are exposed in DVD video lesson that uses purely English language. DVD Video lesson that uses code switching as a medium of instruction in teaching social dance is the useful approach in teaching Grade 10 Special Program in the Art students. The language used (code switching) is the powerful medium of instruction that enhances the learning outcomes of the students to perform well. This paper could be an eye opener to the Department of Education to inculcate the used of first language/local language or MTB- MLE, not only in Grade I to III but all level in K to 12 programs, since education is a key factor for building a better nation.
\end{abstract}

Keywords: code-switching, DVD video lessons, social dance, performance level, special program in the arts

\section{Introduction}

The use of this technology (e.g. video lesson) in the classroom opens many new opportunities for learning that are just beginning to be explored (Cruse, 2011). Nowadays, the multimedia player like android cell phone is common to the 
students to have. It can be a good idea if the video lessons made by the teacher can be transferred to the students' cell phone or other portable media device for them to have a review at home and mastery.

Teachers that uses code-switching in their instruction in the class will lead the students to success in their learning process (Ahmad, B. H., \& Jusoff, K. 2009). The most vital role of the teacher is to help the students to learn for their future. Indeed, using code-switching language, the teacher can help the students in the learning process and value the learners' culture and heritage.

With this idea, the researcher made a DVD video lessons that would enhance the performance of the students in dancing the social dance ( cha cha cha). The study made use of two DVD video lessons in demonstrating the social dance. The first DVD video uses code switching while the other DVD video uses purely English as the medium of instruction. The researcher chooses one of the topics in Physical Education Grade 10 under fourth grading coverage, social dance, specifically the Latin Cha Cha Cha dance.

This paper will mainly focus on which of the two DVD Video Lesson that could enhance the performance level of the Grade 10 SPA students in dancing social dance- Cha Cha Cha. The objectives of the study are to determine:

1. the profile of the respondents in terms of performance level based on the pretest ratings when grouped according to the language used,

2. the profile of the respondents concerning performance level based on the postvideo presentation (post-test) when grouped according to the language used, and

3. if there is a significance difference in the performance grades in Grade 10 SPA class between those students exposed to DVD Video Lesson that uses English language and those students exposed to DVD Video lesson that uses code switching.

The study will benefit to both teachers and students. For the teachers, it will encourage them to make their instructional materials (video lesson) that use code switching for ease of teaching. For the students, the learning process is motivated because the kind of learning they have is not alien to them. Thus, student's participation increases which will result to increase of performance level of the students in the class.

\section{Methodology}

This is a quasi - experimental research using the non- equivalent design with pretest and posttest. It will determine the effect of the performance level in dancing the Cha Cha Cha of the Grade 10 Special Program in the Arts (SPA) students using DVD video lesson that uses code switching as a medium of 
instruction with the group that uses DVD Video lesson that uses English as a medium of instruction also.

This research is anchored to the theory of Salva (2003) that the use of Mother Tongue - Based Multilanguage Education (MTB-MLE) will increase student's participation, gain more attention, interest, and reduces boredom in the class.

\section{Theoretical Framework}

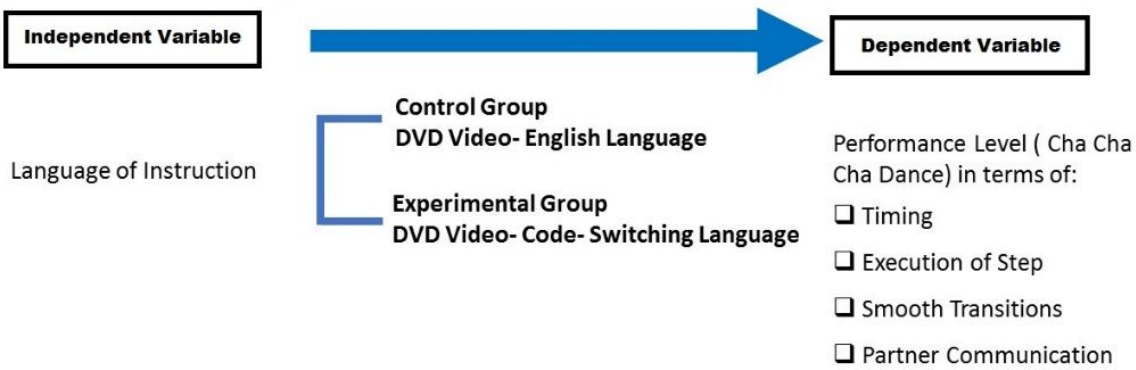

Figure 1: Flow of the Study

Figure 1 displays the theoretical model of the study. It shows the independent and dependent variables are investigated. The left box has an arrow connected going to the right another box. The first box on the right is the Independent Variable, the language of instruction. The language of instruction is the cause why the dependent variables are affected. From the center is the arrow connected the two variables, under of it are the two groups being studied.

These two groups composed of the control group and experimental group. The control group uses DVD Instructional Video material wherein the medium of instruction being used is English. The experimental group uses DVD Instructional Video material wherein the medium of instruction being used is code switching. In grading, the two groups, each participating pair were graded in their performance level using validated rubrics concerning timing, execution of steps, smooth transition, and partner communication.

The researcher facilitated the control group, wherein, the participating pairs of this group will communicate only using English and not allowed to use the local language. The researcher set a rule in this controlled group that whoever communicates with their partner using local language will receive demerits in their performance scores. The second group which is the experimental group was facilitated by the co-teacher of the researcher in the name of Ms. Jorie Dela Torre. The said teacher is a major in PE, and she is teaching the subject for several years 
and completed the academic requirements for her master's degree in Physical Education. In this experimental group, the participating pairs are permitted to communicate with their partner using the code switching. Each participating pair of each group will communicate with their partner only, and they are not allowed to talk to other pairs. The activity was done simultaneously, and wherein two classrooms were used, the first classroom assigned to the controlled group and the second classroom assigned to the experimental group. Each room used the same Audio-Video apparatus.

There were 32 students in the class of 4th year Special Program in the Arts (SPA) that being conducted by this research, 9 are males and 23 are females. The students are instructed to write their name on a piece of paper. The nine (9) names coming from men are collected first, rolled, and randomly distributed to the twocontainer glass. Since the name of the male is odd, the last name is raffled to which container glass will be placed in. The female names were then collected, rolled and placed randomly in the container glass, starting putting in the container glass that contains the odd number of participants (students). Each container glass was labeled one and two. On another container glass, held two sheets rolled paper, group 1 and group 2 . The first one will be drawn will be assigned to the controlled group, and the second, which is the remaining group, will be assigned to the experimental group. Each group has a room for the conduct of this research.

Before the posttest, the pretest was done to each pair. Before each pair enters to the respective room assignment, each pair will perform the pre-test. Pairs were not yet called, will stay outside the room so that they will not see what was happening inside the conduct of the pre-test. After each pair performed the pretest, they will wait inside the room. Until all have been undergone pre-test, the lesson of DVD will start. The purpose of this procedure is to retain the validity of the result, preventing students to talk to other students on what the pre-test is.

In the conduct of posttest, after they finished the DVD Video Lesson, all the participants will stay outside the classroom preventing them from seeing what happened during the posttest. Each pair will be called to perform the dance, and after they are graded using the rubrics, they are not allowed to go out. This purpose is to prevent the students from talking to their classmate what was the posttest.

Each group, the control and the experimental, received the same amount of time in their DVD video Lesson and practice.

In the actual procedure of the pretest-posttest quasi - experimental study, the experimental class was treated with DVD Video Lessons that uses code switching language as a medium of instruction in learning the Cha Cha Cha dance. On the other room, the control group was exposed to DVD Video Lesson that uses the English language as a medium of instruction in learning the said dance. 
Both the experimental and the control group used the same rubrics in the pretreatment and post-treatment phases. The study focused on the significant difference between the posttest scores during the performance evaluation by a pair.

The two DVD video lessons in learning Cha Cha Cha dance were made by the researcher ahead of time already before the conduct of this research proper. The first DVD video lesson, the demonstrator uses purely English as a medium of instruction and the second DVD Video lessons use code switching as a medium of instruction also. Both of the topics contained the two videos are the lesson in Grade 10 , social dance, specifically the Cha Cha Cha dance.

\section{Results and discussion}

Table 1 shows the profile of respondents based on the pretest ratings on the set criteria. The English Group has poor performance rating in timing, spot turn, smooth transition and partner communication. The Code-Switching rated fair in both timing and spot turn while poor in smooth transition and partner communication.

Table 1. Profile of Respondents According to Pre-test Ratings (Proficiency Level) in Performing Cha Cha Cha dance

\begin{tabular}{|l|c|c|c|c|}
\hline \multicolumn{1}{|c|}{ Criteria } & $\begin{array}{c}\text { Average } \\
\text { Rating } \\
\text { (English } \\
\text { Group) }\end{array}$ & Description & $\begin{array}{c}\text { Average } \\
\text { Rating } \\
\text { (Code } \\
\text { Switching) }\end{array}$ & Description \\
\hline Timing & 1.00 & Poor & 2.00 & Fair \\
\hline Spot Turn & 1.25 & Poor & 2.00 & Fair \\
\hline $\begin{array}{l}\text { Smooth } \\
\text { Transition }\end{array}$ & 1.00 & Poor & 1.25 & Poor \\
\hline $\begin{array}{l}\text { Partner } \\
\text { Communication }\end{array}$ & 1.00 & Poor & 1.00 & Poor \\
\hline \multicolumn{1}{|c|}{ Overall } & $\mathbf{1 . 0 6}$ & Poor & $\mathbf{1 . 5 6}$ & Poor \\
\hline
\end{tabular}

The poor results indicate that there is a need for the teacher to be more creative in finding best methods and strategies for the students to be able to understand and develop the right skills expected.

The teacher should be creative in his or her teaching that answers the demands of the global economy by epitomizing, and embedding in instruction, and has a repertoire to develop the mastery of 21st-century skills of the learners such as critical thinking, problem-solving, communication, collaboration and creativity 
and innovation (Kereluik, Mishra, Fahnoe, \& Terry, 2013). It includes how we can apply the technology and appropriate pedagogy in teaching.

Robinson (2010) cited that the learners of the 21st century need to master the academic content and be skilful in critical thinking, communication, technology, and performance to become functional citizens in our society.

As Physical Education teachers, we must be competent in the strategy and technology on how these two can help us in increasing the skills for the performance of our students. They need to be globally competitive to prepare themselves in a real world of the 21st- century needs.

Table 2. Profile of Respondents According to Post Test Ratings Using Set Criteria

\begin{tabular}{|l|c|c|c|c|}
\hline \multicolumn{1}{|c|}{ Criteria } & $\begin{array}{c}\text { Mean } \\
\text { Rating } \\
\text { (English } \\
\text { Group) }\end{array}$ & Description & $\begin{array}{c}\text { Mean } \\
\text { Rating } \\
\text { (Code } \\
\text { Switching } \\
\text { Group) }\end{array}$ & Description \\
\hline Timing & 2.25 & Fair & 4.25 & Outstanding \\
\hline Spot Turn & 1.25 & Poor & 3.00 & Satisfactory \\
\hline $\begin{array}{l}\text { Smooth } \\
\text { Transition }\end{array}$ & 1.25 & Poor & 3.25 & Satisfactory \\
\hline $\begin{array}{l}\text { Partner } \\
\text { Communication }\end{array}$ & 1.37 & Poor & 3.50 & $\begin{array}{c}\text { Very } \\
\text { Satisfactory }\end{array}$ \\
\hline \multicolumn{1}{|c|}{ Overall } & $\mathbf{1 . 5 3}$ & Poor & $\mathbf{3 . 5 0}$ & $\begin{array}{c}\text { Very } \\
\text { Satisfactory }\end{array}$ \\
\hline
\end{tabular}

Table 2 shows the profile of the respondents based on the post-test ratings using set criteria. Among the English group, they perform poorly in spot turn. Smooth transition and partner communication while they rated fairly in timing. The Code- Switching group rates satisfactorily in spot turn and smooth transition, very satisfactorily in partner communication and outstanding in timing.

Fig. 2 shows the results that there is an improvement in the performance ratings of the students after watching the DVD presentation. Comparatively, the experimental group has higher scores compared to the control group. This supports the concepts presented earlier that students learn more effectively when the medium of instruction is that of which they are most familiar with.

Benson (2014) stated that mother tongue-based bilingual education will not only increases way to skills but also boosts the quality of essential education by facilitating classroom interaction and integration of prior knowledge and experiences with new learning. The effects of code switching schooling depict the 
progress made by traditionally marginalized students in the process of being able and even encouraged to demonstrate what they know and participate in their way of learning.

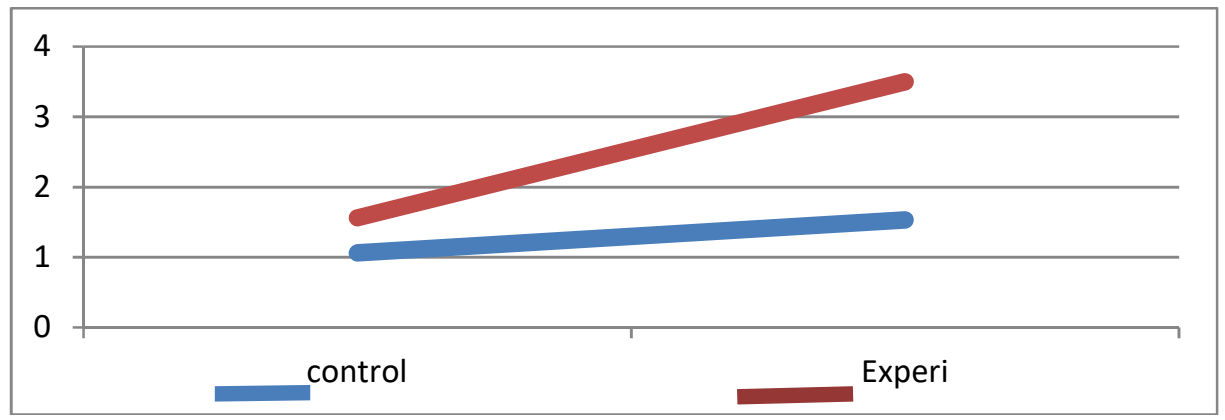

Fig. 2: Profile of Respondents According to Post Test Ratings Using Set Criteria

It is significant evidence that students exposed to their language in lore perform well than those students who are exposed to the language which they don't own. This statement was cited by Johnstone and Selepeng (2004) that students lost $20 \%$ in their learning when the language used is not familiar to them, specifically English.

Table 3 Distribution Table Showing the difference in the Performance Level (posttest) based on actual performance ratings when grouped according to language of instruction used $(\mathrm{P}<0.05)$

\begin{tabular}{|l|c|c|c|c|c|}
\hline \multirow{2}{*}{ Criteria } & \multicolumn{2}{|c|}{ English Group } & \multicolumn{2}{c|}{$\begin{array}{c}\text { Code Switching } \\
\text { Language Group }\end{array}$} & \multirow{2}{*}{ P value } \\
\cline { 2 - 5 } & Mean & Description & Mean & Description & \\
\hline Timing & 2.25 & Fair & 4.25 & Outstanding & $0.0017^{*}$ \\
\hline Spot Turn & 1.25 & Poor & 3.00 & Satisfactory & $0.0102^{*}$ \\
\hline $\begin{array}{l}\text { Smooth } \\
\text { Transition }\end{array}$ & 1.25 & Poor & 3.25 & Satisfactory & $0.0075^{*}$ \\
\hline $\begin{array}{l}\text { Peer } \\
\text { Communication }\end{array}$ & 1.37 & Poor & 3.50 & $\begin{array}{c}\text { Very } \\
\text { Satisfactory }\end{array}$ & $0.0043^{*}$ \\
\hline Overall & 1.53 & Poor & 3.50 & $\begin{array}{c}\text { Very } \\
\text { satisfactory }\end{array}$ & $0.00592^{*}$ \\
\hline
\end{tabular}

* significant at $\mathrm{p}<0.05$ 
Table 3 shows the distribution table showing the difference in the performance level (post-test) based on actual ratings using set criteria. The results showed a significant difference in all the four set criteria namely, timing, spot turn, smooth transition and peer communication. Buhmann and Trudell (2008) stated that mother-tongue-based bilingual education significantly enhances the learning outcomes of students from minority language communities. Since we all know that education is a key factor for the progress of our country, hence we should accept the reality that code switching should be observed in the basic education not only in grade I to III but all the grades in K to 12 Basic Education Curriculum.

\section{Conclusion \& recommendations}

As revealed in the findings, using T- test tested at 0.05 significance level, there is a significant difference in the posttest scores between the experimental group who are exposed to DVD lesson that uses code switching and the control group who used DVD lesson that uses English. Students who are exposed to DVD Video lesson that uses code switching as a medium of instruction performs best.

Students who are exposed to this type of learning should be carefully provided with this kind of video materials to value and appreciate the importance of it. In making this video lesson, it should be properly planned, utilized and carefully evaluated to enhance performance level of the students.

Encourage teachers to make their DVD Video lesson that uses code switching because this is a very powerful tool in increasing the performance of the students. Furthermore, teachers who are not an expert in their subject they taught in their class can use this instructional material (DVD video lesson) to enhance the effectiveness of teaching.

\section{Acknowledgement}

The researcher would like to acknowledge the Department of Education, Division of Cagayan de Oro City, Philippines, for the cooperation during the conduct of this experimental research. Secondly, the National Commission for Culture and the Arts (NCCA) for the scholarship grant given to the researcher to study master in cultural education.

\section{References}

Ahmad, B. H., \& Jusoff, K. (2009). Teachers' code-switching in classroom instructions for low English proficient learners. English Language Teaching, 2(2), 49.

Benson, C. (2014). Adopting a multilingual habitus: What north and south can learn from each other about the essential role of non-dominant languages in 
education. In Minority Languages and Multilingual Education (pp. 11-28). Springer Netherlands.

Bühmann, D., \& Trudell, B. (2008). Mother tongue matters: Local language as a key to effective learning. France: UNESCO.

Cruse, E. (2011). Using educational video in the classroom: Theory, research and practice. Retrieved November.

Darling-Hammond, L. (2012). Powerful teacher education: Lessons from exemplary programs. John Wiley \& Sons.

Greenhill, V. (2010). 21st Century Knowledge and Skills in Educator Preparation. Partnership for 21st Century Skills.

Johnston, P. H. (2004). Choice words: How our language affects children's learning. Stenhouse Publishers.

Kay, K., \& Greenhill, V. (2011). Twenty-first century students need 21st century skills. In Bringing schools into the 21st century (pp. 41-65). Springer Netherlands.

Kereluik, K., Mishra, P., Fahnoe, C., \& Terry, L. (2013). What knowledge is of most worth: Teacher knowledge for 21st century learning. Journal of Digital Learning in Teacher Education, 29(4), 127-140.

Robinson, S. R. (2010). 21st Century Knowledge and skills in Educator Preparation. US: Blackboard, ETS, Intel, National Education Association,.

Sabri Kocakulah, E. U. (2005). The effect of teaching in native and foreign language on students' conceptual understanding in science courses. Asia-Pacific Forum on Science Learning and Teaching, 1-2.

\section{Contact}

Fernando T. Capilitan, Jr. M.Ed.

University Instructor and a Cultural Educator University of Science and Technology of Southern Philippines www.must.edu.ph

College of Science and Technology Education fercaps@gmail.com 